\title{
SUSTAINABLE DEVELOPMENTAND THE PRACTICEOF SPATIAL PLANNING: A PROPOSAL OF CRITERIA FOR MEASURING THE OVERALL SUSTAINABILITY OF PLANNING ACTIONS IN OPEN PUBLIC URBAN SPACES
}

\author{
JOAN NOGUERA ${ }^{1}$, MAR RierA ${ }^{2}$ \\ University of Valencia (Spain)
}

\begin{abstract}
The sustainable city debate is gaining ground in recent years, featuring as a prominent issue in several policy documents of the European Commission, and enjoying support by the main organisations and institutions at international level. At the same time, improving local governance standards by involving citizens in local decision-making is a recurring issue in the debate on local democracy and enhancement of community cohesion. This paper presents an analysis of the European experience and best practice relating sustainable development to the day-to-day practice of spatial planning. The overall purpose is creating a proposal of indicators for measuring the sustainability of planning actions in urban environments.

KEYWORDS: sustainability, public space, spatial planning.
\end{abstract}

JEL CODES: R 58.

\section{Introduction}

This paper presents a review of the European experience and best practice relating sustainable development to the day-to-day practice of spatial planning. The overall purpose is creating a proposal of indicators for measuring the sustainability of planning actions in urban environments. The paper is based on a comprehensive review of best practices on efforts to monitor different dimensions of sustainability in cities and surrounding areas. The review is aimed at building a framework for sustainability "auditing" and a list of clearly definable criteria for the audit. These criteria have been adapted to local conditions through a number of "focus groups" in six countries of the $\mathrm{EU}^{3}$. For each sustainability criteria identified, a number of indicators have been developed in order to facilitate methods for "measuring" the overall sustainability of planning actions for the urban public open space.

From the methodological point of view, the proposal has two input components. On the one hand, a general review of published papers (books, articles, internet pages etc.) which deals both with conceptual issues of sustainability and public participation, and/or presents and discusses examples of best practice or

1 Joan Noguera - professor of Regional Geographical Analysis Department of Geography, Director of the Interuniversity Institute for Local Development, University of Valencia (Spain). Scientific interests: local and regional development, public-private cooperation for development, new factors of territorial development, integrated tourism, knowledge and territorial development

E-mail: Joan.noguera@uv.es

Tel. +34670030377

2 Mar Riera - master in Local Development at the University of Valencia, with one year staying at a Research Institute on Public Policies and Local Governance in Chile. Research interests: development of local and regional strategic planning, sustainability and local development

3 Hungary, Estonia, Greece, Italy, United Kingdom, Belgium and Spain. 
problems related to sustainable open spaces. On the other hand, a compilation of actual examples of best or bad practice.

Data sources have been mainly academic journal databases (i.e. EBSCOHOST and DIALNET), and the Internet. The concepts of sustainable urban planning, public space and citizen participation in planning have been analysed, and main approaches and definitions of sustainability, open space, public space and other related issues have been identified.

\section{Basic concepts}

In recent years increasing attention is being paid to ecological matters when dealing with urban regeneration and development, planning and conservation processes. This is demonstrated by the development of a range of considerations aimed at guiding the achievement of better quality of urban environments. Through the establishment of effective design guidance, it is expected to achieve the enhancement in the use of urban public spaces.

Public open spaces take many different forms: parks, squares, front gardens, river-beds, public gardens, pedestrian precincts, beaches and other. The creation of sustainable open public spaces can deliver a wide range of social and environmental benefits for citizens. Among other, these include attractive, safe and accessible public space, improved health and well-being, improved biodiversity in the urban environment, a community focal point promoting environmental awareness but also, an invigorated area to help attract business investment. Jabareen (2006) identifies four different types of urban forms, which differently contribute to sustainability according to seven design concepts each form relates to.

Creating sustainable public spaces in cities depends on strategic planning and design processes; however, more knowledge is needed on how the right "tools" can be used and the right results delivered. Babalis (2003) recommends that it is essential to delve more deeply in the relation between land use planning, urban design and environmental effects. It is pointed out that, by encouraging different activities and allowing social interaction to take place, the urban open spaces will be revitalized. Only systematic knowledge can contribute to the sustainable development of the cities of the future (Noguera, 2016).

\subsection{Sustainable city and urban development}

Fusco Girard (2011) argues the "happy" city is the city of inclusion, that can satisfy both material and spiritual needs, in which citizens can "be more" and not only "have more" in terms of consumption and material richness: it's the city that allows to satisfy also the needs of justice, supportive co-evolution and beauty.

We can favour citizens to "be more" by making cities more liveable with transport and mobility at the core of the planning dimension, proposing a compact urban model with increasing presence of public transport systems and lower road capacity for private cars to allow for citizens' creativity and innovation. This reasoning underlies on the study for sustainable city development of Kenworthy (2006).

Regardless of single answers, the centrality of social and cultural infrastructure stands out, considering the impossibility of projecting, managing and living the third millennium city only on the basis of the instrumental values of economy, without considering also the "intrinsic" values (i.e. those independent from their use).

The urban challenge is represented by the ability of reproducing values - starting from the ethical, spiritual and religious ones - at a speed at least as equal as the velocity of their consume. The estate of the cultural goods can play a relevant role in the strategies of humanization of urban development.

\subsection{Public space}

A public space is any place that can be freely accessible by the citizenship, regardless of individual conditions (disabilities, age, gender, culture, etc.). It allows for the fulfilment of multiple functions as social relations, exchange and identity building (Carrión, 2007; Bellet, 2009; Martínez Gutiérrez 2010). It is mul- 
tidimensional (physical, social, political, cultural, etc.), and heterogeneous (promote and preserve the communication between social collectives and systems).

The concept of public space has been used by different scientific and technical disciplines for different purposes. According to Martínez Gutiérrez (2010) there are three main analytical perspectives of the public space concept: (i) contributions of the political philosophy; (ii) considerations of the architecture and urbanism; (iii) approaches from the sociology and the anthropology (Table 1). According to this author, public spaces are "scenarios of socialization, spaces where one can enter a relationship. Places for communication, visibility, otherness, transit and trance, learning, evasion, social construction of self and other, mobility with or without displacement, etc. The essence of the city as social and physical form of the coexistence; they allow for the constant society renewal. As spaces of socialization and citizenship, they provide the counterweight to the sociality linked to home as this "external sociality" makes possible the emergence of emancipatory distances, abstract thinking, critical thinking and universal values"4.

Bellet (2009) considers the multidimensionality side of the public space as having many manifestations depending on the focus of analysis: shapes (free space, open space, transactional space), condition (property, management system), uses and functions (common use, shared use, etc.), or type of relations developed (presentation and representation, democracy, protest, leisure, etc.). Bellet (2009) proposes the following dimensions of the public space: (i) a collective and civic dimension in which public spaces are, by definition, plural, flexible and democratic places allowing for the organisation of the social experience; (ii) a symbolic and representational dimension. The main political places of the city being spaces for expression and representation of the citizens. This function of expression and representation generates symbolism associated to experiences and significance of individuals and collectives. Symbolism and representativeness generate urban and territorial references associated to these public places; (iii) a functional dimension in which the public space is the multifunctional place per excellence; (iv) a physical and urbanistic dimension, where public space is open and accessible to everyone (easily reachable, visible, without barriers).

Table 1. Main analytical perspectives of the concept of public space

\begin{tabular}{|l|l|}
\hline \multicolumn{1}{|c|}{ Approach } & \multicolumn{1}{c|}{ Analytical perspective } \\
\hline $\begin{array}{l}\text { Political } \\
\text { philosophy }\end{array}$ & $\begin{array}{l}\text { - Pure political concept associated to the ideal representation of the urban democracy } \\
\text { - Associated to the scope of citizen participation and action } \\
\text { - Main authors: H. Arendt and J. Habermas } \\
\text { - The main challenges for the public space include: the prevalence of individualism, } \\
\text { the substitution of the traditional public politics by a public dialogue based on } \\
\text { commercial marketing }\end{array}$ \\
\hline $\begin{array}{l}\text { Architecture } \\
\text { and urbanism }\end{array}$ & $\begin{array}{l}\text { Physical and material concept associated to the urban structure (street network, } \\
\text { transit, etc.) }\end{array}$ \\
- Usually linked to the concepts of accessibility, morphology and functionality \\
- However, also includes the public space as scenario for interaction of actors: the \\
pulse of the city is measured in its public spaces
\end{tabular}

Source: own elaboration based on www.ecosistemaurbano.org

\subsection{Sustainable urban planning}

There has been a long debate about urban planning over the years. Nowadays, the concept of sustainable urban development is becoming familiar among the urban development literature in different disciplines. Hald (2009) suggests that the sustainable city is a concept that is difficult to translate at the operational level.

While some authors propose integrated planning tools for more sustainable cities (Rotmans, Asselt, Vellinga; 2000), attempts have been made to develop characterizations of sustainable cities or sustainable urban development (Elkin et al., 1991). Such descriptions usually include principles that sustainable urban form 
should adhere to. For example, Elkin et al. state that, "sustainable urban development must aim to produce a city that is 'user-friendly' and resourceful, in terms not only of its form and energy-efficiency, but also its function, as a place for living" (1991: 12).

According to Williams et al. (2000), it appears that there are a variety of urban forms that are more sustainable than others, namely compactness (in various forms), mix of uses and interconnected street layouts, a strong public transportation network, environmental controls and high standards of urban management. Views regarding the sustainability of cities are divided. "While some believe that cities can never be sustainable, others believe that cities can do a great deal to be managed in more sustainable ways (ibid)" (Hald, 2009: 43-44).

This recent city-planning philosophy changes the spatial and the temporal scale, minimizing the space and maximizing the time; it needs to be seen in a regional context and with a long-term perspective due to its far-sighted character to avoid future undesirable and higher cost-efficient management of resources. Thus, long-term planning, a firm compromise (private capital is important in long-term plans) and a subsequent monitoring of the evolution of the actions taken are needed to carry out a real successful sustainable urban plan. As described on the EC Promoting sustainable urban development in Europe. Achievements and opportunities, there are five characteristic features of the sustainable urban development (EC, 2009: 25):

- A move away from individual sectors towards wider integration within the local or regional economy.

- A shift from government to governance, i.e. the tendency of central governments to confer certain duties to lower levels of government, such as provinces, regions, cities, city districts and neighbourhoods (referred to as 'decentralisation'). Together with the privatisation of governmental tasks, this involves the participation of a larger number of different policy partners, organisations and individuals (governance).

- An increasing focus on empowering the inhabitants of cities and specific neighbourhoods.

- A shift from universal policies to more focused, area-based policies.

- Growing attention paid to the effectiveness of policies.

The rising of new concepts and terminologies, the resurgence of a new school of thought and new ways of action related to the present urban paradigm displaced old terms by new ones, as the city-region concept. On behalf of the holistic territorial cohesion concept and the importance of the interrelations between regions, the links between cities and surrounding regions are crucial to improve, coordinate and solve the territorial problems of each area having, as a result, bidirectional benefits for cities and regions (EC, 2009: 18)

Accessibility is a chief and trendy concept on the present urban literature to attain a sustainable territory. It can be physical (i.e. means of transport) or social (i.e. subjective social feeling of how citizens perceive their environment: personal security, levels of attraction, predominance of a concrete group, etc.) (CEC, 2006: 10).

Hald (2009) gives a definition of an eco-city and compares it with a sustainable city. The first one is "a city that provides an acceptable standard of living for its human occupants without depleting the ecosystems and biochemical cycles on which it depends"; the second concept differs from an eco-city on "focusing not only on the environment, but also the broader social and economic context" (Hald, 2009: 44).

According to this reasoning, urban design plays a key role on the sustainable urban development. It is a response of the urban life-style model, but the influence is bidirectional, so addressing designing as a target could change the social pattern behaviours on the territory into win-win situations (e.g. actions as locating the shopping centres in the city, reducing their dimensions, or supporting local businesses without the implantation of big shopping malls). Based on a quotation of the Urban design for sustainability report there are more general actions as: "The introduction of traditional mixes of land uses into mono-use areas may be one approach (as mixed use improves accessibility for everyone and achieves a more balanced use of services and infrastructure including public transport facilities), greater use of home delivery of goods (groceries, household goods) another" (EC, 2004: 14).

Related to integrated transportation in land planning, as described on the Urban design for sustainability report, the 'Transit-Oriented Development model (TOD), sometimes called 'Pedestrian Pockets' is a concept 
of the Californian 'New Urbanist' Peter Calthorpe, which it is a mixed-use community within a 600m walking distance of a core commercial area and rapid transit stop through the rail-based transport system. This concept has its origins in the 'Garden City' ideas of the British reformer, Ebenezer Howard, towards the end of the 19th century' (EC, 2004: 22).

Nijkamp (2008) argues that there is a need for studying cities 'from a computable equilibrium perspective, with a balance between (i) growth-inducing and growth-hampering factors, (ii) multiple (from micro to macro) layers of actors and structures in a city, and (iii) intra-urban and extra-urban force fields.'(Nijkamp, 2008: 15) According to his opinion, a sustainable city development is reached through the balance between positive and negative urban quality conditions (see Table 2).

Table 2. Sustainable urban development: a shaky balance between positives and negatives (OECD 2006), in Nijkamp 2008

\begin{tabular}{|l|l|}
\hline \multicolumn{1}{|c|}{+} & \multicolumn{1}{|c|}{-} \\
\hline Agglomeration economics & Urban deterioration \\
Specialization and diversity & Diseconomies of agglomeration \\
R\&D and innovation & Unemployment \\
Physical capital & Exclusion and poverty \\
(Spatial hub) & Socio-economic inequalities \\
& Immigrants \\
& Criminality \\
& Congestion \\
& Poor-quality infrastructure \\
\hline
\end{tabular}

Source: Nijkamp, 2008

Nijkamp (2008) also addresses the importance of infrastructure (roads, railways, airports, pipelines etc.) and suprastructure (knowledge networks, communication, education, culture etc.) as two major push factors for urban dynamics and economic growth. This author makes a metaphor of the urban world as an alive and dynamic (eco) system and defines modern cities as 'self-organizing innovative complexes' (SIC), subject to the system dynamics. The generic features of such urban or metropolitan SIC are: a reliance on creativity, innovativeness and leadership; competitive advantages to be created by R\&D; productivity and competitiveness as critical success factors; a market orientation determined by product heterogeneity and monopolistic competition; a development path marked by evolutionary complexity and behavioural learning principles.

Furthermore, he estipulates: "Despite the multidimensional complexity of modern cities in their struggle for progress and sustainability, we may distinguish a limited set of systematic factors that exert a decisive impact of the XXQ (high quality conditions for cities) performance of these SIC" (Nijkamp, 2008: 26). These factors which call essentially for an urban systems economics perspective are summarized in Figure 1 in a so-called Pentagon model.

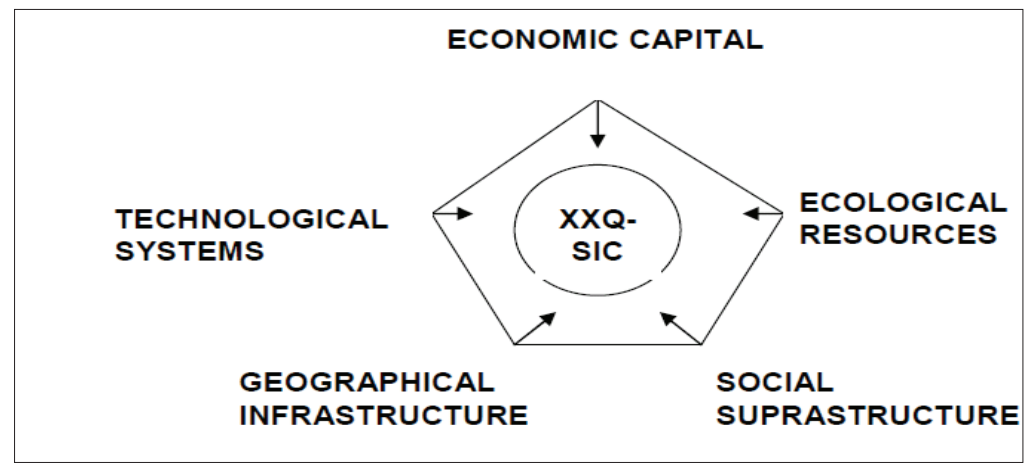

Figure 1. A pentagon model of XXQ forces for SIC

Source: Nijkamp, 2008 


\subsection{Self-financing management of neighbourhoods: increasing sustainability of urban planning}

Conventionally, the financing of an urban project is carried out by private stakeholders or public institutions or organizations (e.g. the four J's, from the 2007-2013 programme of the Cohesion policy, see the report EC, 2009: 36) but an enriched sustainable urban process is better complemented with the participation and support of the local community in all the decision-making process. The Neighbourhood Budgets, or Funds, which have become increasingly popular in the German and Dutch urban policies, consist of facilitating limited budgets to the community that are spent according to their priorities and their own ideas in order to regenerate the district, producing direct effect on the locality and its inhabitants, and increasing their sense of responsibility and ownership (EC, 2009: 37). Nevertheless, it must be pointed out that the three actors (private and public sector and local community) should work together in cooperation to achieve real and sustainable solutions for the neighbourhood. Chiesura (2003) reinforces the role urban parks may play on the sustainability of a city by presenting a study on a Dutch Park in Amsterdam. Results reveal the closer citizens are to the nature experience the more involved is the emotional dimension of human beings resulting in feelings that are more positive and more beneficial services.

\subsection{Alternative settlements. Community modelling sustainability}

The discussion about sustainable urban planning can be argued from the bottom approach perspective, i.e. from the actions of local community initiatives towards a sustainable environment. As stated on the Engaging communities for a sustainable world report, "unlike at the household level, where design options can be limited, nearly the entire metabolism of a community can be adjusted to be more sustainable: from where fresh water is obtained, to how food is produced, to how waste is treated. Most of these take significant time and effort to implement - or financial resources when built by a contractor - but in the end they can help bring the community together (through the planning and construction of the project), cut costs, and reduce ecological impact" (Assadourian, 2008: 153). Self-management is a powerful measure for small-size regions and contrary to the nowadays increase of single-person households' model, only able to be reached if there is a chance for local community to develop their own territory through their solid empowerment.

According to this approach, there are two chief community models: eco-village and co-housing. The first model pretends the total integration of human settlements in the natural world by the development of low environmental impact mechanisms (e.g. solar panel installation, self-food production, rain water collectors as water sources, etc.). Thus, the eco-village model implies a strong personal believe on the self-management philosophy and the care of the environment. It is difficult to insert successfully into the consuming society model because it entails some sort of 'self-sacrifice' measures. Nevertheless, it is important to know it and understand it as a community engagement approach, and a different sustainable development (urban or rural) reality planning. The co-housing model (based on the compact city model) is more focused on community integration by reducing the distances between houses and grouping them to preserve more land and open spaces. Nowadays, there are 385 eco-villages and 500 co-housing projects worldwide. Co-housing is well known in Scandinavia and it is starting now in North America (Assadourian, 2008: 5). These projects could be financed by community development financial institutions (CDFIs), including development banks, credit unions, loan funds, and venture capital funds (Assadourian, 2008: 12)

Community gardens also help the community engagement and reduce costs of food transport (so, they reduce $\mathrm{CO}^{2}$ emissions). According to the above report, "Moreover, having a community garden improved many residents' attitudes about their neighbourhoods, reducing problems like littering, while also spurring broader community revitalization effort" (Assadourian, 2008: 8). They are totally integrated in the urban planning for instance in countries such as England and Germany.

\subsection{Smart growth}

Other important school of thought, related to city planning, is the 'smart-growth'. The aim is to reach sustainability of cities through reducing distances between neighbourhoods but approaching services and 
mixing residences and commerce in the same space. Hence, neighbourhoods will become walkable and not car-dependent. As the mentioned report informs, "One impressive effort is being led by the U.S. Green Building Council (USGBC). This organization's LEED program (Leadership in Energy and Environmental Design) has helped provide green certification schemes for all type of buildings: commercial, residential, and others. USGBC is now working on a new 'LEED for Neighbourhood Development' certification system. This standard, currently in its pilot phase, will provide a grade for planned neighbourhood developments, giving points for designs that connect communities, reduce vehicle use, and create local jobs. It also includes prerequisites such that any development that compromises wetlands or agricultural lands, is located in a flood zone, or is built "60 miles from anything" (as Program Manager Jennifer Henry puts it) cannot be certified. For well-planned neighbourhoods, developers can receive a high grade (platinum or gold), which may help expedite permission from local planning boards and make developers eligible for tax breaks or other incentives" (Assadourian, 2008: 15).

All in all the different approaches to urban planning and development analysed come to agree that there is enough room for improving the degree of integral sustainability of urban environments. New approaches need to explore further the capacity for self-planning and management of neighbourhoods and districts, the possibilities of an active citizenship, or the capacity for introducing innovative measures in the current functioning of the urban fabric that lead to a more sustainable urban "system".

\section{Empirical evidence}

The empirical evidence in this work is based upon a series of best practices identified in different countries of the EU. The aim of the analysis of best practice examples of planning open urban spaces in a sustainable way is to present a compilation of analytical work carried out in relation to sustainable urban planning. A minimum of 10 case studies in each country were selected on the basis of their relevance in the field of sustainable planning of public open urban space. Cases selected belong to different urban elements, urban contexts and urban sizes in Hungary, Estonia, Greece, Italy, United Kingdom, Belgium and Spain. Besides, practices carried out cover a wide variety of examples, from ecological point of view to urban growth restraint, through strategies for sustainable transport facilities. Each example was presented in a standard way, following the template shown in Figure 2.

In order to identify relevant examples we looked in two directions: (i) at existing lists of sustainability criteria (the so called "rulers") and, (ii) at real examples of sustainable public spaces.

\subsection{Rulers for sustainable development}

This 'ruler' is made for professionals and acts as an aid, a tool in defining the level of ambition for an individual project. The ruler is divided in 7 themes with sub themes. Each theme has a range of questions going from basic, to plus and extra plus. The ruler is implemented in development projects, utility projects and dwellings. For this paper the ruler for 'Development' has been selected since it deals with a broader context than 'just' the individual house.

Ecopolis Vlaanderen ${ }^{5}$ developed a 'doe-wijzer'/ act-indicator. It is an instrument to be used by a planner, designer of policymaker to apply the principles of the ecopolis in urban development. The ecopolis is a holistic approach that needs to be "deconstructed" in order to used or implemented. The act-indicator is constructed according to a number of themes: process, optimization of space, vitality and safety, reach and accessibility, soil, nature and landscape, integral water management, sustainable energy management, resources and raw materials, comfort and healthcare.

Each of these themes has a goal. The themes are applied to the level of the neighbourhood and the level of the building. For each of these levels there are a number of steps: (i) preparation; (ii) prevention; (iii) provision of the most sustainable solution.

\footnotetext{
Available at: http://www.ecopolisvlaanderen.be/start.php
} 
Table 3. Template for recording Best Practice examples

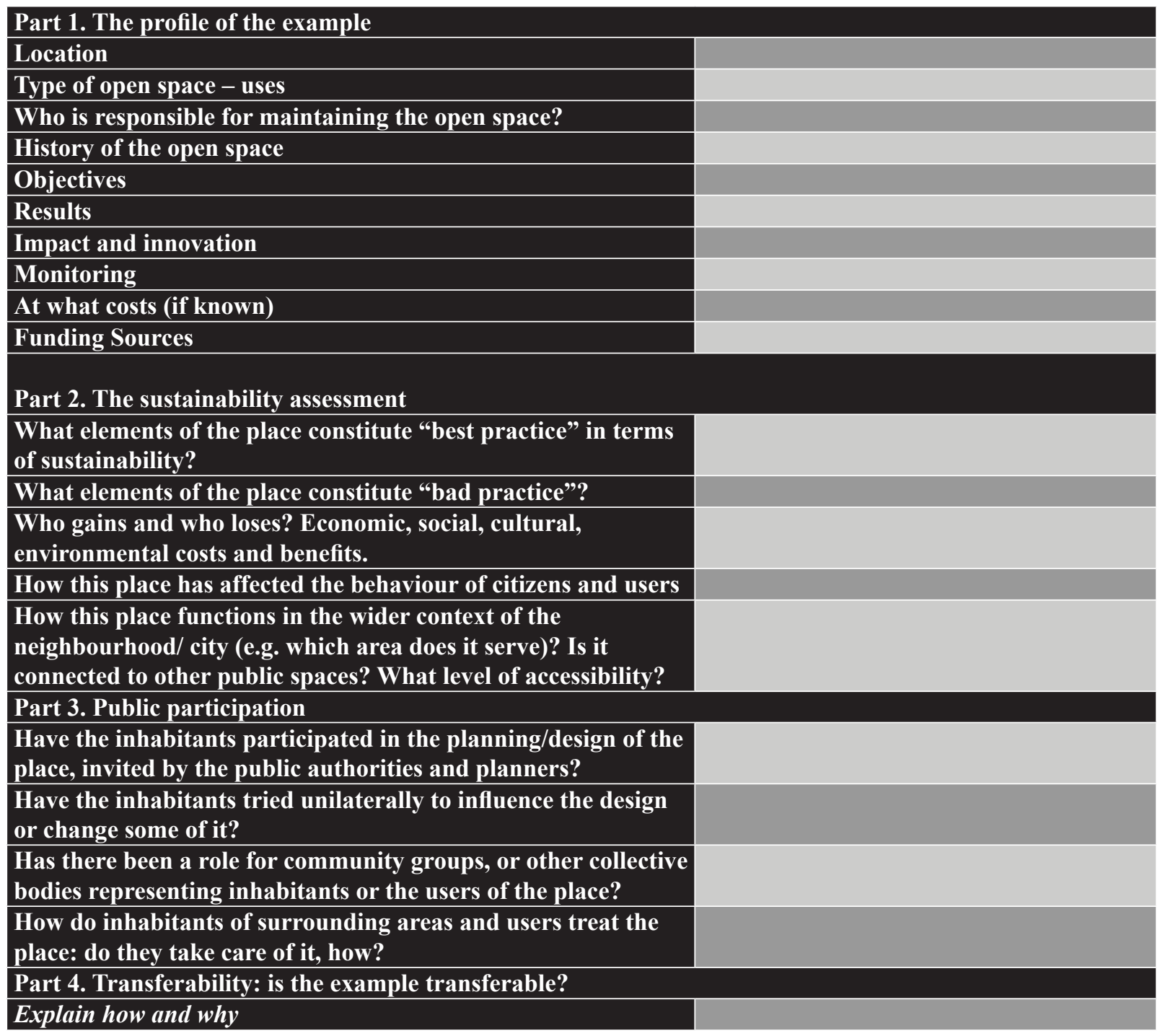

Source: own elaboration

\subsection{Results}

Urban space has historically established a benchmark for the development of individuals and societies. From the primitive functions of protection and defence, the "urban" has acquired new functions in relation to the economy, society, personal fulfilment, cultural expression and configuration of citizenship, among other.

As a result of the secular ability of towns and cities to attract population and economic activity, urban planning has been almost always reactive, since the process of urban development was usually ahead of the planning processes. With the exception of the territories with little or no prior human presence, planning's most general aim has been to address urgent land-use related needs, in response to the problems and challenges caused by the rapid, complex and changing dynamics of urban development.

As shown by the case studies and the focus group, creating green open public spaces or regenerating the existing ones increases the overall quality of life, helps to enhance local identity and the sense of community and also to reduce social exclusion. Urban open space provides a fertile ground for education and awareness rising in relation to a variety of environmental issues, such as biodiversity and ecosystems and how natural systems can be integrated in the everyday life of urban inhabitants. 
The Green Ring of Vitoria-Gasteiz is a best practice example which illustrates all mentioned above. Vitoria-Gasteiz was a city notably damaged by industrial impacts and urban growth, resulting peripheral areas with high ecological and landscape value out into risk. By setting a multifunction green ring around the city (Marañón, 2001) it was possible to bring closer green areas to peripheral neighbourhoods, increasing the connection between these areas thus, reducing social exclusion, improving urban development by planning open public spaces, at the time city green areas increase.

The debate on sustainability in urban planning has some tradition and it has been approached by several disciplines and from different angles. However, in most cases, this debate has focused on the shape of the city as a factor of more or less sustainability. According to this rationale, urban sustainability is reinforced in case of a compact city with a mix of uses that enables an efficient public transport system that is governed by a powerful public management.

However, shape is not the only variable for sustainability if we are to achieve truly sustainable urban areas. The future sustainable planning of urban space should consider the importance of "time" versus the current prevalence of "space"; this requires a long-term planning, legitimized on the basis of a citizen participation process, and integrated planning covering multilevel different scales from local to supranational. Only with these basics will urban planning become more sustainable in the long run.

On the other hand, the achievement of the "sustainable city" will depend on the extent to which it moves from a consideration of the objectives of sustainability as a purely environmental (i.e. more efficient use of resources) to sustainability as a multidimensional concept that incorporate, in addition to the environmental, economic aspects (generation of sustainable economic activity and employment), social (attainment of optimal living conditions and an environment that allows the fulfilment of the potential of each individual).

In recent years, public participation in the design of sustainable public spaces has increased, and there are examples of good practice in the countries such as UK, where communities have been involved in proposing the usage and features of public space, particularly where this relates to their local neighbourhood, to facilitate engagement and future maintenance.

Sustainability of public open spaces is reduced to certain social and economic qualities, because most shareholders agree, that open spaces have to fulfil a minimal ecological standard and a minimal standard of maintenance. We might not talk about a public space, if these standards are not guaranteed. We might not even decide to maintain a public open space, if we cannot guarantee its standard. This might exclude a lot of areas, but sustainability is a qualitative and not a quantitative notion.

Sustainability of public open spaces also might mean something else regarding different cultural and climatic conditions in Europe, but a public space is a sustainable public space, if people feel it is their place and they might feel secure there.

To describe a public space as sustainable, it has to be functional and attractive; to give the user a motive to go there and the opportunity to actually use the space as long as one wishes. Reading spaces, resting corners, playgrounds, sports grounds, cultural facilities, refreshment facilities, environmental awareness facilities are some of the uses that made the examined case studies attractive to visitors. The space has to offer to the user a wide variety of activities so that their stay can be prolonged. It is very important that the space is cool during the hot months, shady and green, and to be offered for recreation and relaxation.

A public open space has to be easily accessible and serve all citizens. It is important to serve a wider area and not only the surrounding neighbourhood; and to be connected with other public spaces or services, especially through public transport.

Despite all the above, there is no doubt that sustainability, in a broad sense, is achieved more easily with the participation of local society. This is the reason why the main European policy documents clearly position themselves in this direction, opting for participatory urban planning, which involves a large number of different policy partners, organisations and individuals, i.e. a change from "government" to "governance" (Bulkeley, Betsill, 2010), and in which the focus is on empowering citizens in the process of designing and implementing policies that shape the city. 


\subsection{Proposed Sustainability Criteria to achieve a more sustainable urban planning process}

This section presents a list of sustainability criteria derived from the review and focus groups in the frame of this research project. Under each title below there is a short discussion on issues regarding sustainability of urban public open spaces and a set of criteria in an attempt to assess the sustainability of an open space.

1. Variety of uses (or users). The main issue addressed is the diversity in the available uses of an open space and how this variety serves the different and often conflicting needs of different users.

Criteria: 1) multi-functionality of an open space to serve the needs of users; 2) capacity for adaptation to changing demands and conditions; 3 ) valorisation of local knowledge.

2. Security / safety. The issue of acceptable levels of security and safety is a complex one and it calls for a negotiation between personal freedom and policing, safety considerations and aesthetic results. Criteria: 1) stablished and clear safety regulations; 2) safe construction materials; 3) participation / involvement of users in security / safety (e.g. through "neighbourhood watch" type of schemes); 4) ease of access in case of emergency; 5) visibility - open field of view; 6) shared space - vs - secluded spaces.

3. Maintenance. Maintenance plays a vital role in the sustainability of an open space and is in constant interaction with other issues of its sustainability, such as safety, environmental sustainability factors or governance. Furthermore, maintenance is an issue that is valid throughout the life cycle of an open space, in planning, designing and use.

Criteria: 1) built-in-maintenance system in design; 2) effective maintenance mechanism in place (staff, organisation, cleaning services etc); 3 ) hardwearing construction materials; 4) voluntary / participatory maintenance schemes (e.g. "adopt a tree / bench" schemes) Involve schools in local projects to "adopt" open spaces; 5) public awareness on maintenance for positive change of behaviour patterns and attitudes; 6) financial sustainability - ensuring funds for the maintenance of open space.

4. Accessibility. Accessibility is an issue touching on three important aspects of access, the ability to reach the open space through transport means, the mobility within the open space (both for pedestrians but also for mothers with baby strollers and very importantly people with disabilities), and thirdly the social aspects of access.

Criteria: 1) transport infrastructure, capacity and planning: Public transport; Private transport; Alternative transport (e.g. bicycles, footpaths etc.); 2) pedestrian mobility without barriers within the open space; 3) mobility considerations for people with disabilities; 4) visibility; 5) orientation signs and other information.

5. Organic relationship of the open space to the city. A very important issue is the existence and the promotion of citizens' feeling of ownership for the public open space and its connection to the surrounding area. This is possible through planning and designing the open space to have an organic relationship to its neighbourhood and the city as a whole, to form a network with other open spaces and its use as a reference point in everyday life.

Criteria: 1) physical cohesion to surrounding infrastructure network (e.g. pathways); 2) social cohesion to the surrounding cultural and social practices; 3 ) functional cohesion and interaction with local amenities; 4) function as an identity point for the neighbourhood / city (defined by users and uses?); 5) connectivity of public open space to networks of other public spaces / services

6. Design and functionality. Design is a factor necessary for every expression of our lives. Especially as regards to open spaces, it can make a public open space usable or un-functional. It incorporates aesthetics, functionality and that little bit extra that gives a space an identity.

Criteria: 1) landscaped open space; 2) attractive amenities and features (furniture, public art works, choice of material); 3) public open space designed with respect to the heritage, identity of the locality and local knowledge; 4) well defined space for different uses.

7. Environmental sustainability. The term sustainability for most people is subconsciously linked to the environment. In an open space the natural environment plays an important role, often affecting 
the surrounding areas by creating a microclimate, and, depending on its size, adding on the environmental balance of the whole city. The application of sustainability principles can lead to an ecologically and socially sound environment.

Criteria: 1) comfort in relation to the climate e.g. protection from the sun-cool places during the summer, sunny spots during cold days, temperature comfort; 2) use of local biodiversity systems (landscape, hiking paths, beach, etc.); 3) indigenous vegetation; 4) local materials; 5) sustainable materials (e.g. permeable paving materials, high reflection / cool materials); 6) controlled level of noise; 7) sustainable resources management, incl. renewed energy input, water management / water recycling; 8) reduced pollution levels; 9) bio-climatic constructions; 10) natural regeneration capacity; 11) low coverage by man-made materials.

8. Governance of public open spaces. The debate on governance of open spaces is an on-going one, with varied opinions on the level of management of sites and on the level of responsibility of different stakeholders. However, one of the factors that are shown to enhance sustainability of an open space, has to do with the cooperation of the public authorities, NGOs and citizens throughout the life cycle of an open space, employing a bottom up approach and methods of public participation. Criteria: 1) accountable processes of local authorities - procurement, publication, dissemination of policies, plans, etc.; 2) adaptation of inclusive policies from local authorities, Social inclusion - social aspects of access; 3 ) acceptance of a bottom-up approach to design from local authorities and planners, making good use of local knowledge; 4) effective Public Participation (Public Participation has an ultimate goal of empowering citizens and actively involving all stakeholders in the decision making throughout design, planning and maintenance of open space. Effective participation presupposes a relationship based on trust and respect between government institutions/authorities and the public, and the achievement of consensus where possible. It can also incorporate conflict resolution. Public Participation promotes the exchange of ideas, beliefs and thoughts in public meetings, open debates, design workshops etc. and every appropriate participation method); 5) effective information communication - clear, to-the-point information, delivered in the most appropriate way, allowing for horizontal communication channels between key actors of the urban planning process. Use of information technology (Web 2.0, blogs, forums, online opinion / participative polls, etc.) where appropriate in order to facilitate dialogue.

9. Carrying capacity. The extent to which a particular area can hold

Criteria: 1) controlling overcrowding through design - environmental and social implications; 2) controlling activities according to carrying capacity of open space; 3) carrying capacity study as part of planning considering future use scenarios.

\section{Conclusions}

The aim of this paper has been reaching a coherent system of criteria to measure the degree of integral sustainability in the processes of planning and development of open urban spaces. Through a literature review and an analysis of more than 60 best practices in six countries the authors come to a substantive list of criteria that can be developed into indicators in order to measure the degree of sustainability of urban projects, plans and practices.

\section{References}

Assadourian, E. (2008). Engaging Communities for a Sustainable World, State of the World Innovations for a Sustainable Economy, p. 151-165. The Worldwatch Institute.

Babalis, D. (2003). Ecological Matters for Good Cities and Environmental Benefits. Florence.

Bellet Sanfeliu, C. (2009). Reflexiones sobre el espacio público. El caso de las ciudades intermedias, Espacios públicos y ciudades intermedias, IV Seminario de la Facultad de Arquitectura y Diseño de la Universidad de los Andes. Mérida, Venezuela, p. 12. 
Bulkeley, H., Betsill, M. (2005). Rethinking Sustainable Cities: Multilevel Governance and the 'Urban' Politics of Climate Change, Environmental Politics, Vol 20, Issue 1, p. 42-63.

Carrión Mena, F. (2007). Espacio público: punto de partida para la alteridad, Espacios públicos y construcción social. Hacía un ejercicio de ciudadanía. Ed. Olga Segovia. Santiago de Chile: Ediciones SUR, p. 79-97. Available at: http://works.bepress.com/fernando_carrion/174

Chiesura, A. (2004). The role of urban parks for the sustainable city. Landscape and Urban Planning, No. 68, p. $129-138$.

Commission of the European Communities. (2006). Communication from to the Commission to the Council and the European Parliament on Thematic Strategy on the Urban Environment. Brussels.

Elkin, T., Mc Laren, D., Hillman, M. (1991). Reviving the city towards sustainable urban development. London: Friends of the Earth Ltd.

European Commission. (2004). Urban Design for Sustainability, Final Report of the Working Group on Urban Design for Sustainability to the European Union Expert Group on the Urban Environment.

European Commission. (2009). Promoting sustainable urban development in Europe: achievements and opportunities. European Commission, Directorate-General for Regional Policy.

Fusco Girard, L. (2011). Creativity and the Human Sustainable City: Principles and Approaches for Nurturing City Resilience. In: L. Fusco, T. Baycan, P. Nijkamp (eds.). Sustainable City and Creativity, promoting creative urban initiatives. Bur lington, Ashgate, p. 55-96.

Hald, M. (2009). Sustainable Urban Development and the Chinese Eco-City. Concepts, Strategies, Policies and Assessments. Norway: Fridtjof Nansen Institute.

Jabareen, Y. R. (2006). Sustainable Urban Forms. Their typologies, models, and concepts. Journal of Planning Education and Research, No. 26, p. 38-52.

Kenworthy, J. R. (2006). The eco-city: ten key transport and planning dimensions for sustainable city development. Environment and Urbanization, No. 1, Vol. 18, p. 67-85.

Marañón, B. (2001). El anillo verde de Vitoria-Gasteiz. Informes de la construcción, Vol. 53. No. 475, p. 73-86.

Martínez Gutiérrez, E (2010). Entrevista a Emilio Martínez Gutiérrez, Ecosistema Urbano, No. 6, Available at: www.ecosistemaurbano.org

Nijkamp, P. (2008). XXQ factors for sustainable urban development: a systems economics view. Romanian Journal of Regional Science, No. 1, Vol. 2, p. 34.

Noguera, J. (2016) “Introducción”. In: J. Noguera (ed.). La visión territorial y sostenible del desarrollo local. Una perspectiva multidisciplinar, p. 11-20. Ed. SEBRAE - Universitat de Valencia. Valencia - Brasilia.

Rotmans, J., van Asselt, M., Vellinga, P. (2000). An integrated planning tool for sustainable cities. Environmental Impact Assessment Review, Vol. 20, Issue 3, p. 265-276.

Williams, K., Jenks, M., Burton, E. (2000). Achieving Sustainable Urban Form. New York: Routledge (Taylor \& Francis).

\section{DARNUS VYSTYMASIS IR TERITORIJŲ PLANAVIMO PRAKTIKA: VIEŠŲJŲ MIESTO ERDVIŲ PLANAVIMO VEIKSMŲ TVARUMO MATAVIMO KRITERIJAI}

JOAN NOGUERA, Mar RIERA

Valensijos universitetas (Ispanija)

\section{Santrauka}

Pastaraisiais metais nemažai diskutuota darnios miestu plètros klausimais, tai atskleidžia keli Europos Komisijos dokumentai ir pagrindinių organizacijų bei institucijų paramos tarptautiniu lygiu paskirstymas. Miesto gyventojų, ekonominès veiklos, infrastruktūros, įrangos ir tinklų koncentracija daro ji sudètinga konstrukcija, iki šiol piliečiai turèjo mažai galimybių (arba iš viso jų neturèjo) pasisakyti miesto projektavimo, planavimo, naudojimo ar perspektyvų klausimais. Neatsitiktinai atsirado įvairių pilietinių judejjimų, kurie siekia, kad būtų patobulinti vietos savivaldos standartai vietovėse, kur kolektyvinis valdymas vietos sprendimų prièmimo procese yra nuolat pasikartojanti problema, siekiant bendruomenès sanglaudos. Šiame straipsnyje pateikiama Europos patirties ir geriausios praktikos analizè, susijusi su darniu vystymu- 
si kasdienėse miestų teritorijų planavimo praktikose, ypač kreipiant dėmesị ị miesto darnumo apskaitos formulių peržiūrą ir analizę. Bendras siekis - sukurti atvirų miesto viešųų erdvių planavimo veiksmų darnumo matavimo rodiklių pasiūlymą. Sukurtos miesto planavimo rodiklių sistemos privalumas: numatyta galimybe įtraukti ir piliečių interesus, be to, suteikiama galimybẻ dalyvauti miesto viešujų erdvių planavimo procese, kur piliečiu vaidmuo yra didelis ne tik dẻl atsiradusios galimybės reikšti nuomonę, kaip naudoti atviras viešąsias erdves, bet taip ịsitraukti ir ị miesto valdymą.

PAGRINDINIAI ŽODŽIAI: darnumas, viešoji erdve, teritoriju planavimas.

JEL KLASIFIKACIJA: R 58.

Received: 2016.04 .03

Revised: 2016.04.23

Accepted: 2016.06.01 